\title{
Capital Punishment in Jewish Law and its Application to the American Legal System: A Conceptual Overview
}

Samuel J. Levine

Touro Law Center, slevine@tourolaw.edu

Follow this and additional works at: https://digitalcommons.tourolaw.edu/scholarlyworks

Part of the Comparative and Foreign Law Commons, and the Other Law Commons

\section{Recommended Citation}

29 St. Mary's L. J. 1037 (1997-1998)

This Article is brought to you for free and open access by the Faculty Scholarship at Digital Commons @ Touro Law Center. It has been accepted for inclusion in Scholarly Works by an authorized administrator of Digital Commons @ Touro Law Center. For more information, please contact Iross@tourolaw.edu. 


\title{
CAPITAL PUNISHMENT IN JEWISH LAW AND ITS APPLICATION TO THE AMERICAN LEGAL SYSTEM: A CONCEPTUAL OVERVIEW
}

\author{
SAMUEL J. LEVINE*
}

I. Introduction............................... 1037

II. Hayes v. Lockhart-A Case in Point .................. 1040

III. Capital Punishment in the Written Torah.............. 1042

IV. Capital Punishment in the Oral Torah............... 1044

V. Conclusion ............................. 1052

\section{INTRODUCTION}

In recent years, a growing body of scholarship has developed in the United States that applies concepts in Jewish law to unsettled, controversial, and challenging areas of American legal thought. ${ }^{1}$ While some scholars endorse the application of Jewish legal theory to American law, ${ }^{2}$

* Assistant Legal Writing Professor \& Lecturer in Jewish Law, St. John's University School of Law; LL.M. 1996, Columbia University; Ordination 1996, Yeshiva University; J.D. 1994, Fordham University; B.A. 1990, Yeshiva University.

I thank Professor Jeff Pokorak, the editors of the ST. MARY's Law Journal, and the Criminal Justice Clinic for inviting me to present my thoughts at their Symposium: The Death Penalty 25 Years After Furman v. Georgia, on March 6, 1998.

1. See Samuel J. Levine, Jewish Legal Theory and American Constitutional Theory: Some Comparisons and Contrasts, 24 Hastings Const. L.Q. 441, 442-43 nn.3-11 (1997) (citing sources which apply Jewish law to American legal theory); Suzanne Last Stone, In Pursuit of the Counter-Text: The Turn to the Jewish Model in Contemporary American Legal Theory, 106 HARv. L. Rev. 813, 814 (1993) (discussing the use of Jewish law in American legal scholarship).

2. See David R. Dow, Constitutional Midrash: The Rabbis' Solution to Professor Bickel's Problem, 29 Hous. L. Rev. 543, 544 (1992) (stating that "the normative ontology of the systems of Jewish and American law are so nearly identical that the Judaic resolution of certain theoretical difficulties can be wholly transplanted to the American domain"); Irene Merker Rosenberg \& Yale L. Rosenberg, Guilt: Henry Friendly Meets the Maharal of Prague, $90 \mathrm{Mich}$. L. Rev. 604, 614-15 (1991). In this Article, Irene and Yale Rosenberg note:

To be sure, Jewish law may be considered irrelevant to American constitutional analysis, separated as the two systems are not only by millennia, but by religious, cultural, social, and economic differences .... That American law does not accept an omniscient and omnipotent God ... does not, however, preclude comparison of the two legal systems. This country is in many ways religiously oriented, and, in any event, 
others are more cautious. $^{3}$ One area of Jewish legal thought that has found prominence in both American court opinions ${ }^{4}$ and American legal scholarship $^{5}$ concerns the approach taken by Jewish law to capital punishment.

moral and ethical beliefs ... surely pervade our society ... . Furthermore, the differences between Jewish and American law should not obscure their similarities .... . Indeed, Jewish law is a fundamental building block of Western civilization. Consciously or not, the United States has adopted basic concepts of Jewish criminal procedure .... Moreover, the Supreme Court itself has referred to Jewish law in support of some of its most important rulings.

3. See, e.g., Steven F. Friedell, Aaron Kirschenbaum on Equity in Jewish Law, 1993 BYU L. REv. 909, 919 (book review) (observing that "Jewish law has policies and purposes that are unique and that make the application of Jewish law in a modern legal system difficult"); Suzanne Last Stone, In Pursuit of the Counter-Text: The Turn to the Jewish Model in Contemporary American Legal Theory, 106 HARv. L. REv. 813, 893-94 (1993) (warning that American theorists "should be cautious not to derive too many lessons from the counter-text of Jewish law," because "Jewish law is not only a legal system; it is the life work of a religious community. The Constitution, on the other hand, is a political document.").

Despite the inherent differences between a religious legal system and a secular one, some conceptual similarities between American law and Jewish law allow for a meaningful comparison of the two systems. See Samuel J. Levine, Jewish Legal Theory and American Constitutional Theory: Some Comparisons and Contrasts, 24 Hastings Const. L.Q. 441, 444 (1997). This Essay focuses on the conceptual similarities between the American and Jewish legal approaches to the death penalty and emphasizes the limitations on such comparisons due to the lack of parallels between religious bases of Jewish law and the American legal system. As Bruce S. Ledewitz and Scott Staples have explained:

[S]imply incorporating Talmudic practice in the American legal system would not be coherent or possible. Nor would it make sense to grant normative supremacy to the

Talmud, per se. The two systems are different; the two societies are different.

So, why compare them? The Talmud is a legal system that aspired to reflect God's purpose in the world. If such a system could confidently put men and women to death, then perhaps so can we. If, on the other hand, the Rabbis of the Talmud agonized over execution, limited its reach, and sought to excuse where possible, perhaps we need to imitate their voices.

Bruce S. Ledewitz \& Scott Staples, Reflections on the Talmudic and American Death Penalty, 6 U. Fla. J.L. \& Pub. PoL'y 33, 37-38 (1993).

4. See Daniel A. Rudolph, Note, The Misguided Reliance in American Jurisprudence on Jewish Law to Support the Moral Legitimacy of Capital Punishment, 33 AM. CRIM. L. REv. 437, 439-41 nn.11-21 (1996) (discussing American court opinions which employed Jewish law).

5. See generally Steven Davidoff, A Comparative Study of the Jewish and the United States Constitutional Law of Capital Punishment, 3 ILSA J. INT'L \& CoMP. L. 93 (1996); Bruce S. Ledewitz \& Scott Staples, Reflections on the Talmudic and American Death Penalty, 6 U. FlA. J. L. \& Pub. PoL'y 33 (1993); Daniel A. Rudolph, The Misguided Reliance in American Jurisprudence on Jewish Law to Support the Moral Legitimacy of Capital Punishment, 33 AM. CRIM. L. Rev. 437 (1996); Aaron M. Schreiber, The Jurisprudence of Dealing with Unsatisfactory Fundamental Law: A Comparative Glance at the Different Approaches in Medieval Criminal Law, Jewish Law and the United States Supreme Court, 
One aim of this Essay is to discuss the issue of the death penalty in Jewish law as it relates to the question of the death penalty in American law, a discussion that requires the rejection of simplistic conclusions and the confrontation of the complexities of the Jewish legal system. For example, it is not uncommon to find both proponents and opponents of the death penalty attempting to support their respective positions through citations to sources in Jewish law. Such attempts, however, often fail to consider the full range of Jewish legal scholarship, relying instead only on sources that appear superficially to favor one position over the other. ${ }^{6}$ Thus, another goal of this Essay is to present a general and balanced overview of Jewish law with respect to legal and historical attitudes towards the death penalty. More specifically, this Essay focuses on the conceptual underpinnings behind pertinent Jewish law, considering the potential relevance and effect of those conceptualizations on American legal thought.

Part II of this Essay discusses the United States appellate court case of Hayes $v$. Lockhart ${ }^{7}$ which makes reference to the death penalty in Jewish law. This case reflects some of the methods employed by members of the legal community who seek to support their positions on the death penalty by referring to Jewish law. Part III takes a close look at the death penalty in the Written Torah, which is often cited by those favoring capital punishment. Part IV examines the complex position taken by the Oral Torah towards the death penalty as reflected in the Talmud and other rabbinic sources. This Essay concludes that any meaningful application of Jewish

11 Pace L. Rev. 535 (1991); Kenneth Shuster, Halacha As a Model for American Penal Practice: A Comparison of Halachic and American Punishment Methods, 19 Nova L. Rev. 965 (1995).

In a recent debate at Georgetown University Law Center entitled "The Modern View of Capital Punishment" the moderator, Professor Samuel Dash, started the discussion with references to the Torah and the Talmud, and observed that "[t]he debate we are going to hear today on the death penalty began many years ago, actually in Biblical times ... and that debate is still here today." Alex Kozinski et al., The Modern View of Capital Punishment, 34 AM. CRIm. L. Rev. 1353-54 (1997).

6. A number of works written in English provide helpful and stimulating discussions of Jewish law as it relates to capital punishment. See generally Basil F. Herring, Jewish Ethics and Halakhah for OUR Time: Sources and Commentary 149-73 (1984); Emanuel B. Quint \& Neil S. Hecht, 1 Jewish Jurisprudence: Its Sources and Modern Applications 154-63 (1980); Adin Steinsaltz, The Essential Talmud 163-74 (Chaya Galai ed., 1976); Gerald J. Blidstein, Capital Punishment-The Classic Jewish Discussion, 14 Judaism 159 (1965); Aaron Kirschenbaum, The Role of Punishment in Jewish Criminal Law: A Chapter in Rabbinic Penological Thought, 9 JEwish L. ANN. 123 (1991); Moshe Sokol, Some Tensions in the Jewish Attitude Toward the Taking of Human Life: A Philosophical Analysis of Justified Homicide in Jewish Legal and Aggadic Literature, 7 JEWISH L. ANN. 97 (1988).

7. 852 F.2d 339 (8th Cir. 1988). 
law to the death penalty debate is impossible without an accurate and complete analysis and understanding of Jewish law in its proper context.

\section{Hayes v. Lockhart-A Case in Point}

The 1988 case of Hayes $v$. Lockhart ${ }^{8}$ offers one example of the injection of Jewish Law into the death penalty debate and illustrates how either side can use Jewish Law to support their respective position. This case illustrates the failure of both sides to appreciate fully the complexity of the Jewish legal system with respect to capital punishment.

In Hayes, the United States Court of Appeals for the Eighth Circuit considered the habeas petition of a defendant who had been convicted of capital felony murder and sentenced to death. During his rebuttal argument at the penalty phase of the trial, the prosecutor referred to a Biblical verse stating "he that strikes a man and he dies shall surely be put to death." 9 Although the majority did not "condone the prosecutor's remarks," it found that the defense counsel's failure to object to the remarks did not constitute ineffective assistance of counsel. ${ }^{10}$

In a dissenting opinion, Judge Bright described the case as involving "a prosecutor's overzealous and unprincipled pursuit of the death penalty and defense counsel's passive response." 11 Judge Bright characterized the prosecutor's "selective quoting" from the Bible as "not only incendiary, but also misleading." 12 Judge Bright also asserted that "[i]n fact, the Old Testament does not advocate the death penalty. Rather, ancient Jewish law abhors the death penalty and sets forth such a multitude of procedural barriers as to render execution, in the words of Gerald Blidstein, 'a virtual impossibility." "13

The prosecutor's reliance on the Biblical verse to support the implementation of the death penalty in the United States was indeed problematic and misplaced. As Judge Bright correctly noted, the prosecutor's citation to the Biblical text without further reference to its foundation in Jewish law resulted in an incomplete and inaccurate interpretation. Thus, Judge Bright's emphasis on the need to consult the work of Jewish legal scholars is instructive, but his brief discussion of the issue is incomplete. The Talmud clearly details the painstaking procedural safeguards that

8. 852 F.2d 339 (8th Cir. 1988).

9. Hayes, 852 F.2d at 356 (Bright, J., dissenting) (quoting the prosecutors reference to biblical passages). The prosecutor appears to have been referring to Exodus 21:12.

10. See id. at 346.

11. Id. at 353 .

12. Id. at 356 .

13. Id. at $356 \mathrm{n} .8$ (quoting Gerald J. Blidstein, Capital Punishment-The Classic Jewish Discussion, 14 Judaism 159, 165 (1965)). 
were required to be observed before the death penalty could be carried out. ${ }^{14}$ Nevertheless, it is evident from Biblical, Talmudic, and post-Talmudic sources that capital punishment was, at times, an actual element of the authority of both the judiciary and the king. ${ }^{15}$

Perhaps more problematic than the failure of both the prosecution and the appellate judges in Hayes to fully investigate the role of the death penalty in Jewish law was the apparently unquestioned notion that the resolution of the religious issue should influence the approach to capital punishment in the United States. One problem is the reliance on an entirely different legal and religious system to help resolve a question of American jurisprudence. The problem arises even though it is not unusual for courts to turn to other legal systems, including the Bible, for guidance in taming unsettled areas of law, particularly those with profound moral implications. ${ }^{16}$ Indeed, the inclusion in this Symposium of a panel relating to the approaches taken to the death penalty by Catholic and Jewish law reflects an assumption that these approaches are somehow relevant to American law.

Another deeper problem lies in the apparent attitudes of the prosecution and Judge Bright in Hayes. There seems to be a disturbing lack of sophistication in the supposition that a simple historical determination of the frequency of death penalty sentences in the Jewish legal system should determine how Jewish law would prescribe death sentences in the American legal system. Such a supposition ignores the fact that Jewish laws are premised on diverse underlying conceptual foundations, some of which may be applicable to American law and others which are rooted in religious principles foreign to American jurisprudential thought. Part III and Part IV examine more closely these conceptual foundations in an attempt to arrive at a more nuanced application of the approach to capital punishment in Jewish law.

14. See infra Part III.

15. See infra notes 47-49, 62-64 and accompanying text. In fact Professor Blidstein observes in the Talmud "expressions of opposition" to a "virtual abolition of the death penalty." Gerald J. Blidstein, Capital Punishment-The Classic Jewish Discussion, 14 JuDAISM 159, 165 (1965). Blidstein further notes that "[i]n practice," post-Talmudic legal authorities "found the abolition of capital punishment ... impossible to maintain." Id. at 170 n.23.

16. See, e.g., Bowers v. Hardwick, 478 U.S. 186, 192 (1986) (noting references to common law and early colonial law); Roe v. Wade, 410 U.S. 113, 160 \& n.57 (1973) (observing that Stoic and Jewish faiths believe life begins at birth); Miranda v. Arizona, 384 U.S. 436, $458 \mathrm{n} .27$ (1966) (commenting on influence of bible in development of analogue to right against self-incrimination). 


\section{Capital Punishment in the Written Torah}

The fundamental source of all Jewish law is the Written Torah-the Five Books of Moses. As the prosecutor in Hayes observed, the Torah does prescribe the death penalty for murder. In fact, those seeking a legal text that incorporates capital punishment as part of the legal system can readily look to the text of the Torah for support, because it contains numerous references to the death penalty. In his Code of Law, Moses Maimonides, the Medieval legal authority, documented the various offenses subject to the death penalty according to the Torah, counting a total of thirty-six such offenses. ${ }^{17}$

Despite the availability of the death penalty for the crimes enumerated in the Torah, reliance on the text of the Torah to support the implementation of the death penalty in the United States is tenuous at best. First, the very fact that the Torah prescribes the death penalty for numerous offenses other than murder represents a fundamental difference between the law of the Torah and American law. Serving as a basic religious document as well as a legal document, the Torah consists not only of civil law but also of ritual law, in addition to historical narrative that pervades and unites the text. The religious nature of the Torah is dramatically illustrated by many of the offenses deemed punishable by death, including for example, various forms of idolatry and violation of the Sabbath. In fact, the majority of capital offenses listed in the Torah relate to purely religious matters, with relatively few involving actions that would be considered criminal in the United States. ${ }^{18}$ Thus, the religious objectives of the legal system manifested in the Written Torah make it an unlikely model for American jurisprudence.

One of the central functions of capital punishment in the Biblical justice system was to provide a means for the offender to atone for the capital offense. ${ }^{19}$ The concepts of repentance and atonement are central to

17. 3 The Code of Moses Maimonides (Mishneh Torah), Book 14, The Book of Judges, Laws Concerning the Sanhedrin and the Penalties Within Their Jurisdiction 15:13, at 44 (Julian Obermann et al. eds. \& Abraham M. Hershman trans., 1949).

18. See Leviticus 20:1-27; Numbers 15:32-36.

19. As Basil F. Herring has stated, "the evil is removed not only from the people of Israel but from the sinner in addition." Basil F. Herring, Jewish ETHICs AND Halakhah for Our Time: Sources and Commentary 157 n.7 (1984). Herring quotes a contemporary scholar who writes that, "Notwithstanding the high regard for man, the cherished value of every unique individual, and the great love that we have for every individual made in the image of God, even those condemned to death ... nonetheless an evil man cannot be permitted to remain alive, for by his death he gains atonement, even as he is removed from life." Id. (quoting B. Rabinowitz-Teomim, Mishpetei Nefashot be'Din haSanhedrin u-ve'Din ha-Malkhut, HA-TORAH VE'HA-MEdinaH 48-50 (1952)). See also Kenneth Shuster, Halacha As a Model for American Penal Practice: A Comparison of Halachic 
Jewish religious thought and practice. ${ }^{20}$ Even those who commit the most grievous sins have the opportunity and obligation to repent from those sins. $^{21}$ Those who commit capital offenses thus receive the harshest of punishments, partly because only such a harsh punishment is considered sufficient to merit complete spiritual atonement. ${ }^{22}$ Although the processes of repentance and atonement are inherent parts of Jewish legal system, that is clearly not the case in American penal law. Various rationales have been offered to support the use of the death penalty in the American criminal justice system, none of which justifies the death penalty on the grounds of repentance. The notion of repentance would presumably be regarded as an unacceptable introduction of a purely religious motive into a criminal penalty. ${ }^{23}$ Any such theory would likely be discredited as a violation of the Establishment Clause, or as a legally improper reliance on religious concepts that have no proper place in American legal thought. ${ }^{24}$

and American Punishment Methods, 19 Nova L. Rev. 965, 974 n.60 (1995) (discussing the role of Halachic punishment in the expiation of sin).

20. See 3 The Code of Moses Maimonides (Mishneh Torah), Book 1, The book of KNowledge, Laws of Repentance (Moses Hyamson trans., 1981); JosePH D. SoloveitchiK, ON REPENTANCE (1984).

21. See 3 The Code of Moses Maimonides (Mishneh Torah), Book 1, The book OF KNOWLEDGE, Laws of Repentance 1:1, at 81b-82a (Moses Hyamson trans., 1981).

22. Indeed, after a conviction on a capital offense, the process of capital punishment includes a mandatory confession as part of the process of repentance and atonement. See 3 The Code of Moses Maimonides (Mishneh Torah), Book 1, The Book of Judges, Laws Concerning the Sanhedrin and Penalties Within Their Jurisdiction 13:1, at 36 (Moses Hyamson trans., 1981).

23. See Bruce S. Ledewitz \& Scott Staples, Reflections on the Talmudic and American Death Penalty, 6 U. FLa. J.L. \& Pub. Pol'y 33, 37 (1993) (citations omitted). As Ledewitz and Staples explain:

The American death penalty differs from that of the Talmud in that it is part of a secular criminal justice system .... the death penalty shows that at least in some contexts, a culture either has a religious perspective or it does not. An important part of the Talmudic death penalty-some say its overriding purpose-was to attain atonement for the condemned through a trial .... The Talmudic death penalty is unfathomable apart from atonement and ritual.

The American death penalty does not have and cannot have, given the assumptions of our constitutional order, any focus on ritual and atonement. It would probably be reversible error for a jury even to consider that by condemning a defendant to death, they might be guaranteeing to him "a portion in the world to come."

24. In recent years, a number of courts have rejected references to religious and Biblical sources in relation to the death penalty. See Bruce S. Ledewitz \& Scott Staples, Reflections on the Talmudic and American Death Penalty, 6 U. FlA. J.L. \& Pub. Pol'y 33, 37 n.22 (1993) (citing cases in which references to religion are rejected); Daniel A. Rudolph, The Misguided Reliance in American Jurisprudence on Jewish Law to Support the Moral Legitimacy of Capital Punishment, 33 Am. CRIM. L. Rev. 437, 438-39 (1996). 
Second, and perhaps more fundamentally, reliance on the text of the Torah to support the death penalty in American law assumes that the text of the Torah is a complete depiction of the Jewish legal system. Such an assumption overlooks another basic premise of Jewish legal and religious thought, which is that as a written text the Torah must be contextually interpreted in order to be understood and applied to a living society. Under Jewish legal theory, in conjunction with the Written Torah, God gave to Moses at Mount Sinai an Oral Torah different from, but equal in authority to, the Written Torah. The Oral Torah was orally transmitted from generation to generation and ultimately compiled as the Talmud. Thus, it is difficult and can be misleading to envision the Jewish legal system based solely on the Written Torah. ${ }^{25}$ The law relating to capital punishment is a prime example of the need to consider both the Oral and Written Torahs because the Written Torah provides broad principles, and the Oral Torah provides most of the legal details that determine the practical application of the law.

\section{Capital Punishment in the Oral Torah}

As Judge Bright accurately observed in Hayes v. Lockhart, ${ }^{26}$ "selective quoting" from the text of the Torah to suggest that the ancient Jewish law supports the use of the death penalty is "misleading."27 Judge Bright further noted that the failure to refer to the Oral Torah ignores the "multitude of procedural barriers" set forth in the Oral Law which render the

For discussions of the place of religion in public spheres, including law and politics, see generally Stephen L. Carter, The Culture of Disbelief: How American law and Politics Trivialize Religion (1993); Kent Greenawalt, Private Consciences and Public Reasons (1995); Kent Greenawalt, Religious Convictions and Political Choice (1988); Michael J. Perry, A Review of Religion in Politics: Constitutional and Moral Perspectives (1997); Frederick Schauer, May Officials Think Religiously?, 27 WM. \& MARY L. Rev. 1075 (1986); Ruti Teitel, A Critique of Religion As Politics in the Public Sphere, 78 CoRnell L. Rev. 747 (1993).

25. For discussions of the history, structure, and methodology of the Jewish legal system, including the relationship between the Written Torah and the Oral Torah, see generally Irving A. Breitowitz, Between Civil law and Religious law: The Plight of The Agunah in American Society 307-13 (1993); Menachem Elon, Jewish Law: History, Sources, Principles 228-39, 281-399 (Bernard Auerbach \& Melvyn J. Sykes trans., 1994); David M. Feldman, Birth Control in Jewish Law: Marital Relations, Contraception and Abortion 3-18 (1968); Aaron Kirschenbaum, EQuity in Jewish Law: Halakhic Perspectives in Law 289-304 (1991); Menachem Elon, The Legal System of Jewish Law, 17 N.Y.U. J. INT'L L. \& PoL. 221 passim (1985); Samuel J. Levine, Jewish Legal Theory and American Constitutional Theory: Some Comparisons and Contrasts, 24 Hastings Const. L.Q. 441, 444-47 (1997).

26. 852 F.2d 339 (8th Cir. 1988).

27. Hayes, 852 F.2d at 356 (Bright, J. dissenting). 
imposition of the death penalty a rare event. ${ }^{28}$ Such safeguards were implemented throughout the Jewish criminal justice process, including during the apprehension of the individual, the introduction of evidence at trial, the deliberations, the rendering of a verdict, and post-verdict proceedings. $^{29}$

The Talmud describes at considerable length the various safeguards to be carried out. Among the most noteworthy safeguards, and perhaps those which most contribute to the infrequency of actual judicial imposition of the death penalty, are: (1) in the process of the apprehension, there must be at least two witnesses who observe the defendant while observing each other; ${ }^{30}$ (2) the defendant must be told in advance of the illegality of the offense; (3) the defendant must immediately declare an intention to commit the offense anyway; and (4) must immediately carry it out. ${ }^{31}$ Throughout the introduction of evidence, each of the witnesses is rigorously cross-examined while being repeatedly reminded of the grave nature of the proceeding and the dearness of the human life at stake. $^{32}$ During the deliberations, any feasible argument for acquittal must be considered by the court, even if the argument was developed by students, who are not allowed to present arguments for conviction. ${ }^{33}$ If a guilty verdict is found to be erroneous, the ruling is reversed, while an erroneous acquittal cannot be reversed. ${ }^{34}$ After a guilty verdict is returned, messengers are dispatched to announce the verdict and call on anyone who can provide exculpatory information; the court then reconvenes to consider any exculpatory information, including claims made by the defendant. ${ }^{35}$ These and numerous other safeguards produced a criminal justice system in which the death penalty was implemented somewhat

28. Id. at $356-57 \mathrm{n} .8$.

29. See Donald L. Beschle, What's Guilt (or Deterrence) Got to Do with It? The Death Penalty, Ritual, and Mimetic Violence, 38 WM. \& MARy L. Rev. 487, 508 (1997) (stating that "[ $t]$ he procedural demands necessary to sustain a capital sentence [in ancient Israel] were increased to a level that would [have] put the Warren Court to shame," and citing observers who "have noted that this same phenomenon has become manifest in contemporary Israel," including "the recent remarkable restraint of Israeli appellate courts in freeing John Demanjanjuk, accused of atrocities during World War II").

30. See 3 The Code of Moses Maimonides (Mishneh Torah), Book 1, The book of Judges, Laws Concerning Evidence 4:1, at 89 (Julian Obermann et al. eds. \& Abraham M. Hershman trans., 1949).

31. See 3 The Code of Moses Maimonides (Mishneh Torah), Book 1, The Book of Judges, Laws Concerning the Sanhedrin and Penalties Within Their Jurisdiction 12:1-2, at 34 (Julian Obermann et al. eds. \& Abraham M. Hershman trans., 1949)

32. See id. 12:3, at 34-36.

33. See id. $10: 8$, at 30.

34. See id. 10:9, at 30-31.

35. See id. 13:1, at 36-37. 
infrequently - certainly not with the frequency that might be suggested by reading the Written Torah alone.

Perhaps the most dramatic and famous expression of the reluctance of ancient Jewish legal authorities to implement the death penalty is found in a Talmudic dialogue between several Rabbis that transpired shortly after the destruction of the Temple in Jerusalem, a time when courts no longer had the authority to adjudicate capital cases.

Without attributing the statement to any particular individual, the Talmud first asserts that a court which implements the death penalty once in seven years is a violent court. ${ }^{36}$ The Talmudic discussion continues with the opinions of authorities who found even rare use of capital punishment to be far too frequent. One such authority is Rabbi Eleazer ben Azaria, who insists that a court that imposes the death penalty even one time in seventy years is a violent court. ${ }^{37}$ The Talmud further documents the views of Rabbi Tarfon and Rabbi Akiva, who declare that, had they been members of a court with the authority to adjudicate capital cases, there would never have been an execution. ${ }^{38}$ Neither Rabbi Tarfon nor Rabbi Akiva explains the precise reason for his absolute opposition to capital punishment, however, the approach appears to be abolitionist in spirit. The discussion concludes with a retort by Rabbi Simeon ben Gamliel that a total abolition of the death penalty would increase the number of murderers. ${ }^{39}$ This response seemingly argues that the death penalty serves in some way as a deterrent to murder and that the abolitionist approach would impede this deterrent effect; the result would be an increase in murders.

Despite the obvious parallels to the current debate over the death penalty, a meaningful application of the views presented in the Talmud requires further analysis of the rationale underlying the various positions, including careful consideration of their religious bases. The abolitionist views of Rabbi Tarfon and Rabbi Akiva, in particular, demand careful examination, because they are sometimes cited in contemporary American legal scholarship to support the abolitionist approach. Indeed, Judge Bright's reference to the "virtual impossibility" of an execution in ancient Jewish law ${ }^{40}$ coincides with the views of Rabbi Tarfon and Rabbi Akiva. It is unlikely that the reluctance of other Rabbis to invoke the death pen-

36. See 4 The Babylonian Talmud, Seder Nezikin, Tractate Makkoth 7a, at 35-36 (I. Epstein ed. \& H.M. Lazarus trans., 1935).

37. See id.

38. See id.

39. See id.

40. See supra notes $10-12$ and accompanying text. 
alty, even one time in seven years or in seventy years, necessarily meant that the practice of execution was nearly extinct.

Scholars have suggested a number of theories to explain the abolitionist positions of Rabbi Tarfon and Rabbi Akiva. ${ }^{41}$ One theory is that Rabbi Tarfon and Rabbi Akiva were concerned with the abiding possibility of human error, despite the numerous and elaborate safeguards already observed as standard procedure in capital cases. ${ }^{42}$ Such concerns certainly resonate throughout the abolitionist movement in the United States. Other scholars suggest that these Rabbis were opposed to capital punishment not only because of the practical uncertainties involved, but because they were opposed to execution in principle, even when the defendant was unquestionably guilty. ${ }^{43}$ According to this theory, the Rabbis felt an overriding concern for the sanctity of human life that outweighed any justification for implementing the death penalty. Again, such an approach has been adopted by modern abolitionists who likewise value human life so highly as to preclude the killing of anyone, even proven murderers. Yet, while the concept of the sanctity of human life certainly has an ethical basis not necessarily rooted in religion, Rabbi Tarfon and Rabbi Akiva likely argued from a decidedly religious perspective, which again raises the question of the propriety of utilizing their opinions to decide legal issues in the United States. ${ }^{44}$

Moreover, the views of Rabbi Tarfon and Rabbi Akiva are not representative of the whole of Jewish law; rather, their opinions are two among many and did not represent the opinions of mainstream Jewish legal authorities. Thus, Judge Bright's statement regarding the "virtual impossi-

41. For a philosophical approach to the debate that attributes absolutist positions to Rabbi Tarfon and Rabbi Akiva and a consequentialist position to Rabbi Simeon ben Gamliel, see Moshe Sokol, Some Tensions in the Jewish Attitude Toward the Taking of Human Life: A Philosophical Analysis of Justified Homicide in Jewish Legal and Aggadic Literature, 7 Jewish L. ANN. 97, 102-05 (1988).

42. See Basil F. Herring, Jewish Ethics and Halakhah for Our Time: Sources AND COMMENTARY 156 (1984). For references to similar concerns in contemporary American legal scholarship, see Kenneth Shuster, Halacha as a Model for American Penal Practice: A Comparison of Halachic and American Punishment Methods, 19 Nova L. REv. 965, 975 n.68 (1995).

43. See Basil F. Herring, Jewish Ethics and Halakhah for Our Time: Sources and Commentary 156 (1984); Gerald J. Blidstein, Capital Punishment-The Classic Jewish Discussion, 14 Judaism 159, 164 (1965).

44. In addition, some Medieval Jewish legal authorities interpreted the abolitionist views of Rabbi Tarfon and Rabbi Akiva as referring only to periods of proliferation in murders; according to these authorities, under ordinary conditions these Rabbis would not support an abolitionist approach. See Basil F. Herring, Jewish Ethics and HalakhaH for OUR Time: Sources ANd Commentary 156 (1984). 
bility" of an execution in ancient Jewish law reflects a minority opinion. ${ }^{45}$ In fact, Professor Blidstein, on whose article Judge Bright's statement was based, deemed Rabbi Akiva to be "the final expositor of a muted tradition." ${ }^{36}$ Blidstein further observed that Rabbi Simeon ben Gamliel, who contested the views of Rabbi Tarfon and Rabbi Akiva, "was probably not alone in protesting this virtual abolition of the death penalty. His is merely the clearest voice." 47 The view of Rabbi Simeon ben Gamliel appears to find support in other rabbinic statements, which dispute the overriding concerns that motivated Rabbi Tarfon and Rabbi Akiva. For example, the Rabbis of the Talmud comment on the Biblical verse which instructs that in executing a murderer, "do not pity him." the Rabbis, this verse was a response to those who would oppose the execution of a murderer on the grounds that, because the victim is already dead, the taking of another life serves no purpose. ${ }^{49}$ As Blidstein explains, "[h]owever generous the motive, the perversion of justice is evil, its motivation misguided. The Rabbis feared that true love of humanity could only be undermined by indiscriminate recourse to 'mercy,' which, as Rabbi Simeon ben Gamliel pointed out, would deny an innocent society the concern shown the criminal." 50

Similarly, those opinions which decried the use of the death penalty even one time in seven years or in seventy years do not necessarily support opposition to the death penalty in the United States. It is evident that Rabbis who made such statements, despite registering their disapproval of the common use of the death penalty, were not confessed abolitionists. At best, to incorporate such views into American jurisprudence would be to suggest that the current number of executions in the country as a whole-and in the State of Texas in particular-should decrease considerably to prevent the development of "violent courts" in the United States.

45. In addition to authorities who openly dispute the views of Rabbi Tarfon and Rabbi Akiva, a Talmudic discussion of the different opinions suggests that a majority of Rabbis disagreed with the approach of Rabbis Tarfon and Akiva. See 4 The Babylonian Talmud, Seder Nezikin, Tractate Makkoth 7a, at 35-37 (I. Epstein ed. \& H.M. Lazarus trans., 1935).

46. Gerald J. Blidstein, Capital Punishment-The Classic Jewish Discussion, 14 JUDAISM 159,165 (1965).

47. Id.

48. Deuteronomy 19:13.

49. See Midrash Tannaim (commenting on Deuteronomy 19:13) (cited in BasIL F. Herring, Jewish Ethics and Halakhah For Our Time: Sources and Commentary $152(1984))$.

50. Gerald J. Blidstein, Capital Punishment-The Classic Jewish Discussion, 14 JudAISM 159, 167 (1965). 
Even this modest hypothesis, however, is an inconclusive inference from the statements of the Rabbis. Although their views appear to be based purely on the number of executions that take place, the Rabbis' primary concerns might instead be with the number of executions relative to the general population. Consider that the Jewish population in the land of Israel at that time was probably no larger than a few million; ${ }^{51}$ thus, the Rabbis' statements criticized the execution of one out of a few million individuals every seven or seventy years. A proportionate analysis in the United States, a nation of nearly three hundred million people, would result in the condemnation of the execution of approximately one hundred people every seven or seventy years. Although this analysis still supports a suspension in the current pace of executions, the resulting criticism of the current system is somewhat muted. Another relevant consideration is that the Rabbis issued their opinions in the context of a society that was probably not plagued by the level of violence currently experienced in United States. ${ }^{52}$ Had they been theorizing in a more violent society, the Rabbis may have approved of larger number of executions.

Conversely, the intense degree of violence that has permeated the United States may ultimately provide the most convincing argument that Jewish law would not support this nation's implementation of the death penalty. The Talmud indicates that forty years prior to the destruction of the Second Temple in Jerusalem, the Sanhedrin-the High Courtmoved from its location near the Temple in order to negate its own authority to adjudicate capital cases. ${ }^{53}$ According to the Talmud, upon the proliferation of capital offenses, the Court recognized that it could no longer judge these cases properly and subsequently decided not to render death sentences any longer. ${ }^{54}$ Despite the mainstream acceptance of capital punishment, the Rabbis evidently believed - and acted accordingly-

51. See 13 EnCyClopedia Judaica 871-72 (1971) (estimating the Jewish population in the Land of Israel "shortly before the fall of Jerusalem" in 70 C.E. at "not more than $2,350,000-2,500,000$ " and noting that after the fall of Jerusalem, "[u]nquestionably the total number of Jews rapidly declined").

52. Professors Ledewitz and Staples suggest that "[t]he differences between Israel in the period of time before the reduction of the Talmud and America today are obviously great .... The most significant difference between ancient Israel and modern America is the level of violence." See Bruce S. Ledewitz \& Scott Staples, Reflections on the Talmudic and American Death Penalty, 6 U. Fla. J.L. \& Pub. Pol'y 33, 36 (1993).

53. See 4 The Babylonian Talmud, Seder Nezikin, Tractate Abodah Zarah 8 b, at 42 (I. Epstein ed. \& A. Cohen trans., 1935).

54. The precise rationale for the Sanhedrin's actions remains nebulous. See id.; Aaron Kirschenbaum, The Role of Punishment in Jewish Criminal Law: A Chapter in Rabbinic Penological Thought, 9 Jewish L. AnN. 123, 141 (1991); Bruce S. Ledowitz \& Scott Staples, Reflections on the Talmudic and American Death Penalty, 6 U. FLA. J.L. \& PUB. PoL'Y 33, 36 (1993). 
that if capital offenses are committed to such an extent that courts lose their ability to properly adjudicate such cases, then the death penalty should be suspended. ${ }^{55}$ It follows from this view that the proliferation of murders in the United States mandates at least a temporary cessation of capital punishment. ${ }^{56}$

Finally, two factors remain that could complicate any attempt to oppose the death penalty by reference to Jewish law. Both factors involve fundamental components of the Jewish legal system that do not have parallels in American law. The first factor, as previously stated, concerns the uniquely religious considerations that often underlie principles in the Jewish criminal justice system. ${ }^{57}$

The willingness of Jewish legal authorities to limit the use of the death penalty was based, at least in part, on an abiding trust in God as the ultimate arbiter of justice. The Talmud relates the belief that even when the High Court ceased to adjudicate capital cases, the Heavenly Court continued to mete out the death penalty through a variety of apparently natural or accidental events. ${ }^{58}$ In contrast to the belief in an ultimately Divine form of justice, the United States criminal justice system is premised on the principle that the nation's courts are the final forums of justice. ${ }^{59}$ Hence, the view towards man-made justice in the United States is fundamentally inconsistent with the religiously-based aspects of Jewish law that allow for the limitation or abolishment of capital punishment.

55. Basil F. Herring has cited the view that "when the crime rate increases, indicating that the deterrent function of the death penalty is irrelevant, there is even more reason to oppose its implementation." Basil F. Herring, Jewish Ethics and Halakhah for Our Time: Sources AND Commentary 161 (1984).

56. Professors Ledewitz and Staples reason that "[i]f we are to have a death penalty at all, with over 20,000 homicides a year, it must be a massively widespread penalty compared to that of Israel." Bruce S. Ledowitz \& Scott Staples, Reflections on the Talmudic and American Death Penalty, 6 U. Fla. J.L. \& PuB. PoL'y 33, 36 (1993). They conclude that "[t]he Rabbis of the Talmud could not have accepted the routinization of the death penalty necessitated by such large numbers." Id.

57. See notes 20-26 and accompanying text.

58. See 3 The Babylonian Talmud, Seder Nezikin, Tractate Sanhedrin 37b, at 235-36 (I. Epstein ed. \& Jacob Shachter trans., 1935); see also Aaron Kirschenbaum, The Role of Punishment in Jewish Criminal Law: A Chapter in Rabbinic Penalogical Thought, 9 Jewish L. AnN. 123, 138-41 (1991).

59. See Irene Merker Rosenberg \& Yale M. Rosenberg, Guilt: Henry Friendly Meets the Maharal of Prague, 90 MicH. L. Rev. 604, 614-15 (1991) (contrasting the American criminal justice system's approach to guilt with the Jewish legal system's underlying assumption that "in any case of acquittal of the factually guilty, God will ultimately assess culpability correctly and completely and punish accordingly"). Despite this contrast, the authors cite a number of similarities between the two systems and endorse "meaningful comparison of the Jewish and American views on factual and legal guilt." Id. at 616; see also supra note 3. 
The second factor complicating the use of Jewish law to oppose the death penalty is that Jewish law provides for extrajudicial imposition of capital punishment. ${ }^{60}$ For example, the Talmud instructs that if the "needs of the hour" so demand, a court may issue a capital sentence without invoking the ordinary evidentiary and procedural safeguards. The Talmud also permits, under extraordinary circumstances, the imposition of the death penalty for offenses that are not ordinarily considered capital offenses. $^{61}$ In addition, if a murderer is not subject to the death penalty through the usual judicial process, then the King has the prerogative to execute the murderer based on "societal need" and "the needs of the hour."62

The very fact that Jewish law authorizes multiple means for imposing capital punishment weakens modern attempts to rely on Jewish law to oppose the death penalty. ${ }^{63}$ It is clear that the extrajudicial imposition of capital punishment is extraordinary even within the Jewish legal system and has no parallel in American law. The existence of extrajudicial alternatives to the judicial imposition of capital punishment probably provided a measure of assurance to some of those authorities who limited the judicial enforcement of the death penalty. ${ }^{64}$ If so, it is perhaps less certain that these authorities provide support for modern opponents of

60. See Aaron M. Schreiber, The Jurisprudence of Dealing with Unsatisfactory Fundamental Law: A Comparative Glance at the Different Approaches in Medieval Criminal Law, Jewish Law and the United States Supreme Court, 11 PACE L. REv. 535, 545-51 (1991).

61. See 3 The Babylonian Talmud, Seder Nezikin, Tractate Sanhedrin 46a, at 303, 72a, at 488-89 (I. Epstein ed. \& H. Freedman \& Jacob Shachter trans., 1935). For discussions of the court's exigency jurisdiction, see BASIL F. HERRING, JEwISH ETHICS AND Halakhah for Our Time: Sources and Commentary 158-59 (1984); Emanuel B. Quint \& Neil S. Hecht, 1 Jewish Jurisprudence: Its Sources and Modern ApPliCATIONs 139-213 (1980); Aaron Kirschenbaum, The Role of Punishment in Jewish Criminal Law: A Chapter in Rabbinic Penalogical Thought, 9 JEwish L. ANN. 123, 132-35 (1991).

62. See Maimonides, Code of Law, (Mishneh Torah), Book 14, The Book of JudGes, Laws of Murder 2:4 (Julian Obermann et al. eds. \& Abraham M. Hershman trans., 1949); see generally J. David Bleich, Jewish Law and the State's Authority to Punish Crime, 12 Cardozo L. Rev. 829 (1991); Arnold N. Enker, Aspects of Interaction Between the Torah Law, the King's Law, and the Noahide Law in Jewish Criminal Law, 12 CARdozo L. REV. 1137 (1991).

63. See Aaron M. Schreiber, The Jurisprudence of Dealing with Unsatisfactory Fundamental Law: A Comporative Glance at the Different Approaches in Medieval Criminal Law, Jewish Law and the United States Supreme Court, 11 PACE L. REV. 535, 545-51 (1991).

64. See Aaron Kirschenbaum, The Role of Punishment in Jewish Criminal Law: A Chapter in Rabbinic Penalogical Thought, 9 Jewish L. ANN. 123, 141 (1991) (asserting "[o]nly the exigency jurisdiction of the courts ... remained to cope with the proliferation of murderers, plunderers and men of violence"). 
[Vol. 29:1037

capital punishment in the United States, where there are no extrajudicial means for imposing capital punishment.

\section{Conclusion}

Any student of the law who studies the Jewish legal system and the American legal system will observe many parallels in both substance and methodology. As a result of these parallels and the apparent similarities in the moral beliefs found in Jewish tradition and American society, some legal scholars look to Jewish law to help resolve complex issues in American law, particularly those with deep moral implications.

Inasmuch as the death penalty persists as one of the most complex and controversial moral questions in American legal thought, it is not surprising that courts and legal scholars have turned to Jewish law for guidance. Unfortunately, however, references to Jewish law in the area of the death penalty are often incomplete and inaccurate. A prudent application of Jewish law to the modern death penalty requires a complete analysis of the Jewish legal system in its proper context. In particular, one must acknowledge, appreciate, and understand the interaction between fundamental legal and religious principles that are central to Jewish law in order to make meaningful and illuminating comparisons and contrasts between the Jewish and American legal systems. 